\title{
HYPOGLYCEMIC AND HYPOLIPIDEMIC EFFECTS OF ETHANOL ROOT EXTRACT OF CLERODENDRUM PHLOMIDIS IN ALLOXAN-INDUCED DIABETIC RATS
}

\author{
MRUNAL DINESH SHANBHAG, GOWRI RADHAKRISHNAN* \\ Department of Pharmacognosy, Faculty of Pharmacy, M. S. Ramaiah University of Applied Sciences, Bengaluru, Karnataka, India. \\ Email: gowrijp@gmail.com
}

Received: 15 May 2018, Revised and Accepted: 21 July 2018

\begin{abstract}
Objective: In traditional systems of medicine numerous plants have been used for the treatment and control of diabetes. Clerodendrum phlomidis is the accepted botanical source of the ayurvedic drug Agnimantha. The plant is used in the treatment of smallpox, inflammation, coryza, scrotal enlargement, syphilitic, and postnatal complaints. The roots are used to treat measles, gonorrhea, and diabetes. The present study aims at evaluating the hypoglycemic and hypolipidemic activity of $C$. phlomidis roots.
\end{abstract}

Methods: Diabetes was induced by administering $120 \mathrm{mg} / \mathrm{kg}$ alloxan monohydrate intraperitoneally in albino Wistar rats for a treatment period of 21 days during which body weight changes and fasting blood glucose (FBG) were monitored at weekly intervals. On the $21^{\text {st }}$-day serum biochemical parameters, liver malondialdehyde, reduced glutathione, and glycogen levels were estimated.

Results: The ethanol extract at $400 \mathrm{mg} / \mathrm{kg}$ dose significantly $(\mathrm{p}<0.001)$ reduced the elevated FBG and serum biochemical parameter levels.

Conclusion: The present study substantiates the traditional use of $C$. phlomidis in the treatment of diabetes.

Keywords: Alloxan, Antidiabetic activity, Clerodendrum phlomidis, Hypolipidemic, Liver glycogen.

(C) 2018 The Authors. Published by Innovare Academic Sciences Pvt Ltd. This is an open access article under the CC BY license (http://creativecommons. org/licenses/by/4. 0/) DOI: http://dx.doi.org/10.22159/ajpcr.2018.v11i11.27305

\section{INTRODUCTION}

Diabetes mellitus is a chronic metabolic disorder affecting a large number of people in the world. Nearly 285 million people of the world population were known to be affected by diabetes in the year 2010, and this number may increase up to 439 million by 2030 [1]. This metabolic disorder occurs due to defects in insulin secretion and action. As the insulin secretion is hampered, it directly affects the action of insulin on glucose metabolism resulting in loss of homeostasis of glucose in the body. This also causes impaired metabolism of fats, carbohydrates, and proteins [2]. Diabetes mellitus is also characterized by glucosuria, ketonemia, hyperglycemia, and negative nitrogen balance which is caused due to deficiency of insulin [3].

Diabetes mellitus can be treated by improving the availability of insulin in the body and also by overcoming the resistance of insulin. To improve the insulin available to the body, drugs underclass of sulfonylurea, and meglitinide are used. Drugs belonging to biguanides, thiazolidinediones, and $\alpha$-glucosidase inhibitors are used to overcome insulin resistance. Apart from these commercially available synthetic drugs diabetes can also be treated with herbal drugs. There is a great demand for a new ayurvedic based drug for diabetes in the developed and developing countries because of their wide biological activities and higher safety margin than the synthetic drugs. In Ayurveda, plants such as Phyllanthus amarus, Gymnema sylvestre, Trigonella foenum, Terminalia chebula, and Momordica charantia [4] are used in the management of diabetes mellitus.

Agnimantha is one of the important drugs in Ayurveda [5]. The accepted botanical source of Agnimantha is $C$. phlomidis L.f. belonging to the family Verbenaceae [6]. The plant is used in the treatment of smallpox, inflammation, coryza, scrotal enlargement, syphilitic, and postnatal complaints [7-9]. Roots are used in the treatment of measles, gonorrhea, diabetes, and as a bitter tonic [5]. Some species of Clerodendrum such as Clerodendrum serratum (leaves) [10],
Clerodendrum viscosum (leaves) [11], and Clerodendrum inerme (aerial parts) [12] are reported for antidiabetic activity. C. phlomidis is traditionally used in the treatment of diabetes [13], but significant hypoglycemic and other pharmacological activities are reported on the leaves although root being the part of the plant used (crude drug). In a clinical trial, the hypoglycemic activity of $C$. phlomidis leaf was found to be effective compared to tolbutamide [13]. Since no work has been reported on the antidiabetic activity of $C$. phlomidis roots, the present study has been undertaken.

\section{METHODS}

Chemicals

Alloxan monohydrate was procured from Avra Synthesis Pvt, Ltd., Hyderabad, India, and all the reagent kits were obtained from Robonik Pvt. Ltd., Navi Mumbai, Maharashtra, India, and Diatek, Kolkata, India.

\section{Plant material}

The root of $C$. phlomidis was collected from Thoothukudi district of Tamil Nadu, India in January 2017. The plant was identified and authenticated by Dr. V. Chelladurai, Taxonomist. Herbarium of the plant material was prepared [14] and deposited in the herbarium of Department of Pharmacognosy, Faculty of Pharmacy, M. S. Ramaiah University of Applied Sciences, Bengaluru, Karnataka, India (Voucher specimen No. 052).

\section{Preparation of ethanol extract}

Total ethanol extract was prepared by extracting powdered crude drug with $95 \%$ ethanol by continuous hot percolation using Soxhlet apparatus. The extract was filtered and concentrated to dryness under reduced temperature and pressure. Preliminary phytochemical screening was performed for the detection of primary and secondary metabolites $[15,16]$.

Determination of total phenolic and flavonoid content

The total phenolic content was determined by Folin-Ciocalteu method using gallic acid as standard [17] and total flavonoid content was 
estimated by aluminum chloride colorimetric assay using Quercetin as a standard drug [18].

\section{Animals}

Healthy Albino Wistar rats of either sex weighing 200-300 g were used. The animals were housed in the Animal House of Department of Pharmacology, Faculty of Pharmacy, M. S. Ramaiah University of Applied Sciences, Bengaluru, Karnataka, India. All the animals had free access to food and water ad libitum and were kept under laboratory condition (12 $\mathrm{h}$ day and $12 \mathrm{~h}$ night cycle at $21 \pm 2^{\circ} \mathrm{C}$ ). All diseased rats and those outside the weight range were excluded from the study. The study protocol was approved by the Institutional Animal Ethics Committee (IAEC No.: XVIII/MSRFPH/M-04/08.02.2017).

\section{Acute toxicity study}

Acute toxicity of ethanol root extract was determined as per the OECD guidelines 423 . Limit test was performed by administering a dose of $2000 \mathrm{mg} / \mathrm{kg}$ of ethanol extract to a group of 3 female animals. Animal behavior and toxicity signs were observed for 15 days and further until the end of the study [19].

\section{Induction of diabetes}

Diabetes was induced in the experimental animals by administering a single dose of $120 \mathrm{mg} / \mathrm{kg}$ body weight of alloxan monohydrate intraperitoneally. After 7 days, animals with fasting blood glucose (FBG) level of more than $200 \mathrm{mg} / \mathrm{dL}$ were considered as diabetic and used for the study [20-22].

\section{Experimental protocol}

Nondiabetic rats served as normal group animals, and the diabetic animals were grouped into 4 groups of 6 animals each.

\begin{tabular}{ll}
\hline Group & Treatment \\
\hline I & Normal control (2\% acacia) \\
II & Positive control (alloxan $120 \mathrm{mg} / \mathrm{kg}$ ) \\
III & Standard drug (glibenclamide $0.5 \mathrm{mg} / \mathrm{kg}$ ) \\
IV & Ethanol extract test dose $200 \mathrm{mg} / \mathrm{kg}$ \\
V & Ethanol extract test dose $400 \mathrm{mg} / \mathrm{kg}$ \\
\hline
\end{tabular}

On $0,7^{\text {th }}, 14^{\text {th }}$, and $21^{\text {st }}$ day, body weight changes and FBG levels of animals in all groups were monitored.

\section{Estimation of biochemical parameters}

On the $21^{\text {st }}$ day, animals were fasted overnight, anesthetized with ether anesthesia and blood was withdrawn from retro-orbital plexus. Serum was separated from the blood by centrifugation at 10,000 rpm for $10 \mathrm{~min}$ (Micro Centrifuge, REMI Motors Ltd, Mumbai) for the estimation of various biochemical parameters such as glycosylated hemoglobin (HbA1c), triglycerides (TG), total cholesterol (TC), highdensity lipoprotein (HDL), and total protein using reagent kits. Lowdensity lipoprotein (LDL) and very low-density lipoprotein (VLDL) levels in the serum were derived using Friedewald's formula:

Low-density lipoprotein (LDL) concentration $(\mathrm{mg} / \mathrm{dL})=$ Total cholesterol - (HDL cholesterol + Triglycerides/5)

Verylow-densitylipoprotein (VLDL) concentration (mg/dL) = Triglycerides $/ 5$

Further, the animals were sacrificed with thiopental sodium, and the liver was isolated for the estimation of malondialdehyde (MDA), reduced glutathione and glycogen levels [23,24].

\section{Histopathological studies}

All the animals were sacrificed on the $21^{\text {st }}$ day, and necropsy was carried out. The pancreases were collected, washed with normal saline and kept in $10 \%$ formalin solution. Paraffin sections were made at $5 \mathrm{~mm}$ thickness using a microtome processed in alcohol-xylene series. It was stained with eosin and hematoxylin, mounted on the glass slide for histopathological evaluation.
Oral glucose tolerance test (OGTT)

OGTT was performed in normal rats (Albino Wistar strain) of either sex weighing from 200 to $300 \mathrm{~g}$. The animals were divided into 5 groups consisting of 6 animals each in a group. The animals were fasted overnight before the study. During the treatment, Group I served as control and received $2 \%$ acacia solution (p.o.). Group II served as positive control and did not receive any treatment before administration of $2 \%$ glucose solution (p.o.). Group III served as standard and received $0.5 \mathrm{mg} / \mathrm{kg}$ dose of glibenclamide (p.o.). Groups IV and $\mathrm{V}$ received low and high (200 and $400 \mathrm{mg} / \mathrm{kg}$ ) doses of ethanol extract (p.o.). After 60 min of standard and extract administration, all animals were given $2 \mathrm{~g} / \mathrm{kg}$ body weight of glucose (p.o). Immediately blood samples were collected at every $0,30,60,90$, and 120 min from the tail vein and blood glucose levels were checked using an ACE Blood Glucometer [25].

\section{Statistical analysis}

The data were expressed as a mean \pm standard error of the mean values and tested with one-way analysis of variance followed by Tukey-Kramer multiple comparison tests.

Table 1: Phytochemical screening of $C$. phlomidis ethanol root extract

\begin{tabular}{ll}
\hline Test for & Ethanol extract \\
\hline Alkaloids & + \\
Carbohydrates & + \\
Phytosterols & + \\
Fixed oil and fats & - \\
Phenolic compounds and tannins & + \\
Glycosides & - \\
Saponins & - \\
Flavonoids & + \\
Proteins and amino acids & - \\
\hline
\end{tabular}

+: Present, -: Absent, C. phlomidis: Clerodendrum phlomidis

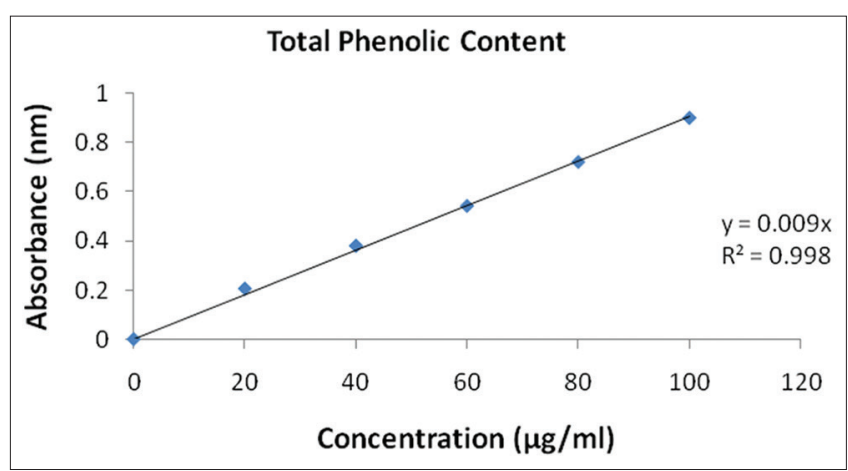

Fig. 1: Calibration curve of standard gallic acid

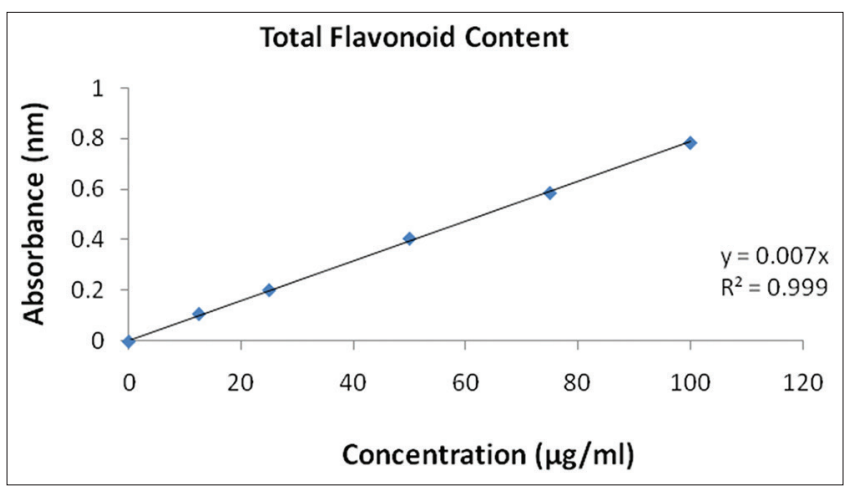

Fig. 2: Calibration curve of standard quercetin 


\section{RESULTS}

\section{Phytochemical studies}

The preliminary phytochemical screening of the ethanol extract of C. phlomidis root was shown in Table 1.

\section{Total phenolic and flavonoid content}

The calibration curve of gallic acid and quercetin was derived and presented in Figs. 1 and 2. The phenolic and flavonoid content of ethanol root extract was shown in Table 2 .

\section{Acute toxicity study}

The acute toxicity study of ethanol extract did not show any toxic symptoms or death at $2000 \mathrm{mg} / \mathrm{kg}$ dose for up to 15 days. Hence, $1 / 5^{\text {th }}$ and $1 / 10^{\text {th }}$ of the maximum dose tested were selected for the evaluation of the antidiabetic activity.

\section{Antidiabetic activity}

Effect on body weight and FBG level

The normal and standard treated group animals showed a weight gain of 1.67 and $9.5 \mathrm{~g}$, respectively. The extract treated animals at a dose of

Table 2: Total phenolic and flavonoid content of ethanol root extract of $C$. phlomidis

\begin{tabular}{lll}
\hline Extract & $\begin{array}{l}\text { Total phenolic content } \\
\text { GAE } \mathbf{( m g / g )}\end{array}$ & $\begin{array}{l}\text { Total flavonoid } \\
\text { content } \mathbf{( m g / g )}\end{array}$ \\
\hline Ethanol extract & 89.22 & 61.17 \\
\hline
\end{tabular}

C. phlomidis: Clerodendrum phlomidis, GAE: Gallic acid equivalent
200 and $400 \mathrm{mg} / \mathrm{kg}$ showed a significant increase in body weight of 5.66 and 8.5 g, respectively, whereas positive control group showed a weight loss of $17.17 \mathrm{~g}$ (Table 3).

On the 0 day, the FBG level of all the experimental animals was found to increase after administration of $120 \mathrm{mg} / \mathrm{kg}$ dose of alloxan monohydrate (i.p.). The animals treated with Glibenclamide $0.5 \mathrm{mg} / \mathrm{kg}$ showed extremely significant $(p<0.001)$ decrease in FBG level when compared to positive control on the $21^{\text {st }}$ day of the study. At $400 \mathrm{mg} / \mathrm{kg}$ dose, ethanol root extract showed significant $(\mathrm{p}<0.001)$ decrease in FBG level compared to positive control (Table 4).

\section{Effect on serum biochemical parameters}

Lipid profile

Administration of alloxan at a dose of $120 \mathrm{mg} / \mathrm{kg}$ caused a significant $(p<0.001)$ increase in TC, TG levels, and reduction in HDL levels compared to the control group. The diabetic animals treated with glibenclamide $0.5 \mathrm{mg} / \mathrm{kg}$ showed extremely significant $(\mathrm{p}<0.001)$ decrease in TC and TG levels in comparison to the positive control group. Animals treated with C. phlomidis ethanol root extract at high dose level $(400 \mathrm{mg} / \mathrm{kg})$ showed extremely significant $(\mathrm{p}<0.001)$ decrease in $\mathrm{TC}$ and TG levels (Table 5).

\section{HbA1c}

There was a significant $(\mathrm{p}<0.001)$ elevation in $\mathrm{HbA1c}$ level in positive group animals when compared to control group. Animals treated with ethanol extract at both dose levels (200 and $400 \mathrm{mg} / \mathrm{kg}$ ) showed extremely significant $(\mathrm{p}<0.001)$ decrease in elevated HbA1c level in comparison to positive control group (Table 5).

Table 3: Effect of ethanol root extract of $C$. phlomidis on body weight

\begin{tabular}{lllll}
\hline Group & Treatment & Mean initial body weight $(\mathrm{g})$ & Mean final body weight $(\mathrm{g})$ & Mean weight gain/weight loss $(\mathrm{g})$ \\
\hline I & Normal & $255.83 \pm 25.82$ & $257.5 \pm 25.77$ & $1.67 \uparrow$ \\
II & Positive control & $287 \pm 22.36$ & $269.83 \pm 21.45$ & $17.17 \downarrow$ \\
III & Glibenclamide $(0.5 \mathrm{mg} / \mathrm{kg})$ & $287.5 \pm 22.63$ & $297 \pm 24.66$ & $9.5 \uparrow$ \\
IV & Ethanol extract $(200 \mathrm{mg} / \mathrm{kg})$ & $260 \pm 13.33$ & $265.66 \pm 17.03$ & $5.66 \uparrow$ \\
V & Ethanol extract $(400 \mathrm{mg} / \mathrm{kg})$ & $293.66 \pm 25.81$ & $302.16 \pm 27.57$ & $8.5 \uparrow$ \\
\hline
\end{tabular}

C. phlomidis: Clerodendrum phlomidis

Table 4: Effect of $C$. phlomidis on fasting blood glucose in alloxan-induced diabetic rats

\begin{tabular}{llllll}
\hline Group & Treatment & FBG $(\mathbf{m g} / \mathbf{d l})$ & & \\
\cline { 3 - 6 } & & $\mathbf{0}$ day & $\mathbf{7}^{\text {th }}$ day & $\mathbf{1 4}^{\text {th }}$ day & $\mathbf{2 1}^{\text {st }} \mathbf{d a y}$ \\
\hline I & Normal & $89.84 \pm 5.54^{* * *}$ & $90.82 \pm 5.25^{* * *}$ & $91.01 \pm 5.22^{* * *}$ & $91.50 \pm 5.12^{* * *}$ \\
II & Positive control & $213.80 \pm 3.48^{\mathrm{a}}$ & $214.65 \pm 4.38^{\mathrm{a}}$ & $215.39 \pm 4.04^{\mathrm{a}}$ & $216.65 \pm 2.58^{\mathrm{a}}$ \\
III & Glibenclamide $(0.5 \mathrm{mg} / \mathrm{kg})$ & $202.88 \pm 2.85^{* * *}$ & $187.83 \pm 3.30^{* * *}$ & $160.74 \pm 7.65^{* * *}$ & $123.76 \pm 3.52^{* * *}$ \\
IV & Ethanol extract $(200 \mathrm{mg} / \mathrm{kg})$ & $206.84 \pm 3.16^{\text {ns }}$ & $203.64 \pm 2.65^{\text {ns }}$ & $199.49 \pm 1.67^{\text {ns }}$ & $187.77 \pm 3.89^{*}$ \\
V & Ethanol extract $(400 \mathrm{mg} / \mathrm{kg})$ & $207.67 \pm 2.80^{\text {ns }}$ & $201.77 \pm 2.08^{\text {ns }}$ & $189.91 \pm 1.32^{* *}$ & $144.15 \pm 6.13^{* * *}$ \\
\hline
\end{tabular}

Values are expressed as mean \pm SEM and statistically analyzed by one-way ANOVA followed by Turkey Kramer multiple comparison tests. ${ }^{* * *}<<0.001,{ }^{* *}$ p $<0.01$, ${ }^{*} \mathrm{p}>0.05$, ${ }^{\mathrm{ns}} \mathrm{p}>0.05$ in comparison with positive control. ${ }^{\mathrm{a}} \mathrm{p}<0.001$ in comparison with normal control. C. phlomidis: Clerodendrum phlomidis, FBG: Fasting blood glucose, SEM: Standard error of mean

Table 5: Effect of ethanol root extract of C. phlomidis on serum biochemical parameters

\begin{tabular}{|c|c|c|c|c|c|c|c|c|}
\hline Group & Treatment & TP (mg/dl) & HbA1c (\%) & TC (mg/dl) & TG (mg/dl) & HDL (mg/dl) & LDL (mg/dl) & VLDL (mg/dl) \\
\hline I & Normal & $9.11 \pm 0.13^{* * *}$ & $5.58 \pm 0.56^{* * *}$ & $139.22 \pm 1.76^{* * *}$ & $72.23 \pm 1.24^{* * *}$ & $84.03 \pm 2.73^{* * *}$ & $40.74 \pm 2.01^{* * *}$ & $14.11 \pm 0.25^{* * *}$ \\
\hline II & Positive control & $4.06 \pm 0.82^{\mathrm{a}}$ & $9.27 \pm 0.56^{\mathrm{a}}$ & $187.97 \pm 2.53^{\mathrm{a}}$ & $168.04 \pm 4.00^{\mathrm{a}}$ & $48.74 \pm 3.73^{\mathrm{a}}$ & $104.98 \pm 4.17^{\mathrm{a}}$ & $33.60 \pm 0.79^{\mathrm{a}}$ \\
\hline III & Glibenclamide $(0.5 \mathrm{mg} / \mathrm{kg})$ & $9.06 \pm 0.22 * * *$ & $6.12 \pm 0.08^{* * *}$ & $143.94 \pm 2.14^{* * *}$ & $78.53 \pm 3.38^{* * *}$ & $80.05 \pm 2.73^{* * *}$ & $48.18 \pm 1.94^{* * *}$ & $15.70 \pm 0.66^{* * *}$ \\
\hline IV & Ethanol extract $(200 \mathrm{mg} / \mathrm{kg})$ & $4.60 \pm 0.25^{\mathrm{ns}}$ & $7.2 \pm 0.04^{* * *}$ & $170.44 \pm 4.63^{* *}$ & $110.12 \pm 6.06^{* * *}$ & $64.03 \pm 1.34^{*}$ & $84.53 \pm 3.31^{* *}$ & $22.02 \pm 1.21^{* * *}$ \\
\hline V & Ethanol extract (400 mg/kg) & $8.21 \pm 0.19 * * *$ & $6.31 \pm 0.05^{* * *}$ & $146.30 \pm 1.60^{* * *}$ & $81.07 \pm 1.81^{* * *}$ & $86.59 \pm 0.55^{* * *}$ & $43.48 \pm 1.78^{* * *}$ & $16.10 \pm 0.45^{* * *}$ \\
\hline
\end{tabular}


Effect on liver antioxidants levels

The positive control group showed significant $(\mathrm{p}<0.001)$ increase in MDA and decrease in reduced glutathione levels when compared to control group. Administration of ethanol root extract of $C$. phlomidis for 21 days at both the dose levels showed extremely significant $(\mathrm{p}<0.001)$ decrease in MDA level and increase in reduced glutathione level, and the values were comparable with standard glibenclamide $(0.5 \mathrm{mg} / \mathrm{kg})$ (Table 6).

\section{Liver glycogen}

There was an extremely significant $(\mathrm{p}<0.001)$ decrease in liver glycogen levels of positive control animals when compared to vehicle-treated group. Treatment of glibenclamide at a dose of $0.5 \mathrm{mg} / \mathrm{kg}$ showed extremely significant $(\mathrm{p}<0.001)$ increase in liver glycogen level in comparison to the positive control group. Treatment with ethanol extract at dose of $400 \mathrm{mg} / \mathrm{kg}$ showed significant ( $p>0.05)$ increase in liver glycogen level in comparison to positive control (Table 6).

\section{OGTT}

Administration of glucose $2 \mathrm{~g} / \mathrm{kg}$ caused a significant $(\mathrm{p}<0.001)$ elevation in blood glucose level of the animals at a different time interval $(0,30,60,90$, and $120 \mathrm{~min})$ when compared to the positive control group. Treatment with glibenclamide $(0.5 \mathrm{mg} / \mathrm{kg})$ significantly $(\mathrm{p}<0.01$; $\mathrm{p}<0.001$ ) lowered the blood glucose level at different time interval in comparison to positive control. Groups treated with ethanol extract at low- and high-dose level (200 and $400 \mathrm{mg} / \mathrm{kg}$ ), respectively, showed significant $(\mathrm{p}>0.05 ; \mathrm{p}<0.01 ; \mathrm{p}<0.001)$ decrease in blood glucose level at different time intervals when compared to positive control group. The ethanol extract was found to be effective to stimulate the pancreatic $\beta$ cells to secrete insulin after an overdose of glucose maintaining a normal blood glucose level (Table 7).

\section{Histopathological studies}

The pancreas of control group animals showed lobular cells surrounded by islets of Langerhans. The acinar cells are surrounded with intact interlobular connective tissue and polygonal cells are arranged normally. The pancreas of positive control animals showed congested dilated blood vessels and degeneration of islet cells. Glibenclamide (standard) treated group pancreas showed regeneration of islets cells surrounded by acinar cells. The pancreas of animals treated with ethanol extract ( 200 and $400 \mathrm{mg} / \mathrm{kg}$ ) showed regeneration of islet cells (Fig. 3a-e).

\section{DISCUSSION}

Preliminary phytochemical screening of ethanol extract showed the presence of alkaloids, carbohydrates, phytosterols, and phenolic compounds such as flavonoids and tannins. The ethanol extract was found to contain $89.22 \mathrm{mg} / \mathrm{g}$ of phenolic and $61.17 \mathrm{mg} / \mathrm{g}$ of flavonoid content. Acute toxicity study revealed that the extract did not show any toxic symptoms at a dose of $2000 \mathrm{mg} / \mathrm{kg}$. Hence, $1 / 5^{\text {th }}$ and $1 / 10^{\text {th }}$ of the maximum dose administered were selected for the antidiabetic study.

Antidiabetic activity of the root extract of $C$. phlomidis was evaluated by alloxan-induced diabetic model. The diabetogenic action of alloxan is mainly due to the formation of reactive oxygen species as a result of the reduction of alloxan to diuretic acid in the pancreas or due to its potential to react with protein $\mathrm{SH}$ group of the pancreatic $\beta$ cells causing cell death. The free radicals formed causes cell death by damaging the DNA of the $\beta$ cells leading to induction of Type II diabetes [26]. During the study, body weights of the animals were monitored at weekly intervals, and it was found that the extract treated groups showed a significant increase in body weight when compared to standard. In diabetic condition, the body either does not produce insulin or fails to secret or use insulin effectively leading to insulin deficiency which causes rapid gluconeogenesis. Administration of ethanol extract of $C$. Phlomidis at a higher dose ( $400 \mathrm{mg} / \mathrm{kg}$ ) for 21 days showed a significant decrease in FBG level when compared to positive control.

Insulin is responsible for lipid metabolism as it inhibits the process of lipolysis. In diabetic condition, the action of insulin is altered due to the deficiency of insulin causing the release of free fatty acids which undergo $\beta$-oxidation resulting in increase in TC levels. Insulin deficiency inhibits the metabolism of LDL due to a decrease in 3-hydroxy-3-methylglutarylcoenzyme A reductase activity. The decrease in enzyme activity leads to an increase in LDL concentration giving rise to lipid deposition. Lack of insulin also leads to deposition of TGs due to inactivation of the enzyme protein lipase responsible for hydrolysis of TGs. Hence, in diabetic condition, there is an increase in TC, LDL, TG levels, and decrease in HDL level due to metabolic abnormalities [2,21]. The elevated TC, TGs, and LDL and VLDL levels in diabetes-induced animals were significant decrease in the group treated with $400 \mathrm{mg} / \mathrm{kg}$ ethanol root extract of C. phlomidis when compared to the positive control animal. The HDL levels were also restored to the normal levels in the extract treated group.

Table 6: Effect of $C$. phlomidis on liver antioxidants and glycogen levels

\begin{tabular}{lllll}
\hline Group & Treatment & MDA (nmoles/100 mg) & Reduced glutathione (nmoles/100 mg) & Glycogen (mg/100 mg) \\
\hline I & Normal & $0.203 \pm 0.03^{* * *}$ & $71.18 \pm 1.81^{* * *}$ & $2.88 \pm 0.28^{* * *}$ \\
II & Positive control & $0.88 \pm 0.06^{\mathrm{a}}$ & $17.55 \pm 1.40^{\mathrm{a}}$ & $0.81 \pm 0.22^{\mathrm{a}}$ \\
III & Glibenclamide $(0.5 \mathrm{mg} / \mathrm{kg})$ & $0.337 \pm 0.02^{* * *}$ & $66.37 \pm 0.83^{* * *}$ & $2.61 \pm 0.24^{* * *}$ \\
IV & Ethanol extract $(200 \mathrm{mg} / \mathrm{kg})$ & $0.529 \pm 0.03^{* * *}$ & $55.86 \pm 3.93^{* * *}$ & $1.73 \pm 0.09^{\text {ns }}$ \\
V & Ethanol extract $(400 \mathrm{mg} / \mathrm{kg})$ & $0.324 \pm 0.02^{* * *}$ & $65.30 \pm 1.80^{* * *}$ & $2.04 \pm 0.12^{*}$ \\
\hline
\end{tabular}

Values are expressed as mean \pm SEM and statistically analyzed by one-way ANOVA followed by Turkey Kramer multiple comparison tests. ${ }^{* * *}<<0.001,{ }^{* *} \mathrm{p}<0.01$,

${ }^{*} \mathrm{p}>0.05,{ }^{\mathrm{n}} \mathrm{p}>0.05$ in comparison with positive control. ${ }^{\mathrm{p}} \mathrm{p}<0.001$ in comparison with control. SEM: Standard error of the mean, C. phlomidis: Clerodendrum phlomidis, MDA: Malondialdehyde

Table 7: Effect of $C$. phlomidis on OGTT in normal rats

\begin{tabular}{|c|c|c|c|c|c|c|}
\hline \multirow[t]{2}{*}{ Group } & \multirow[t]{2}{*}{ Treatment } & \multicolumn{5}{|c|}{ Blood glucose level (mg/dl) } \\
\hline & & 0 min & $30 \mathrm{~min}$ & $60 \mathrm{~min}$ & $90 \mathrm{~min}$ & $120 \mathrm{~min}$ \\
\hline $\bar{I}$ & Normal & $46.33 \pm 1.11^{* * *}$ & $64.5 \pm 4.08^{* * *}$ & $92 \pm 1.98^{* * *}$ & $86.33 \pm 1.90^{* * *}$ & $65.03 \pm 4.67^{* * *}$ \\
\hline II & Positive control (2 g/kg glucose) & $89.83 \pm 4.43^{\mathrm{a}}$ & $122.83 \pm 2.28^{\mathrm{a}}$ & $128.66 \pm 1.99^{a}$ & $118 \pm 2.03^{\mathrm{a}}$ & $91.16 \pm 2.27^{\mathrm{a}}$ \\
\hline III & Glibenclamide $(0.5 \mathrm{mg} / \mathrm{kg})$ & $85.16 \pm 2.35^{\mathrm{ns}}$ & $117.16 \pm 2.34^{* *}$ & $127.83 \pm 2.58^{* *}$ & $114.16 \pm 2.02^{* * *}$ & $88 \pm 3.60^{\mathrm{ns}}$ \\
\hline IV & Ethanol extract ( $200 \mathrm{mg} / \mathrm{kg})$ & $71.5 \pm 3.18^{*}$ & $78.3 \pm 3.14^{* * *}$ & $80.66 \pm 2.90^{* * *}$ & $79.33 \pm 2.92^{* * *}$ & $75.83 \pm 2.57^{\mathrm{ns}}$ \\
\hline $\mathrm{V}$ & Ethanol extract (400 mg/kg) & $74.16 \pm 3.32^{\mathrm{ns}}$ & $110 \pm 4.76^{\mathrm{ns}}$ & $135.83 \pm 8.36^{\mathrm{ns}}$ & $117.16 \pm 8.49^{* *}$ & $84.5 \pm 5.01^{\mathrm{ns}}$ \\
\hline
\end{tabular}

Values are expressed as mean \pm SEM and statistical analysed by one-way ANOVA followed by Turkey Kramer multiple comparison tests. ${ }^{* * *} \mathrm{p}<0.001,{ }^{* *} \mathrm{p}<0.01,{ }^{*} \mathrm{p}>0.05$, ${ }^{\mathrm{n}} \mathrm{p}>0.05$ in comparison with positive control. ${ }^{\mathrm{a}} \mathrm{p}<0.001$ in comparison with control. SEM: Standard error of the mean, C. phlomidis: Clerodendrum phlomidis, OGTT: Oral glucose tolerance test 

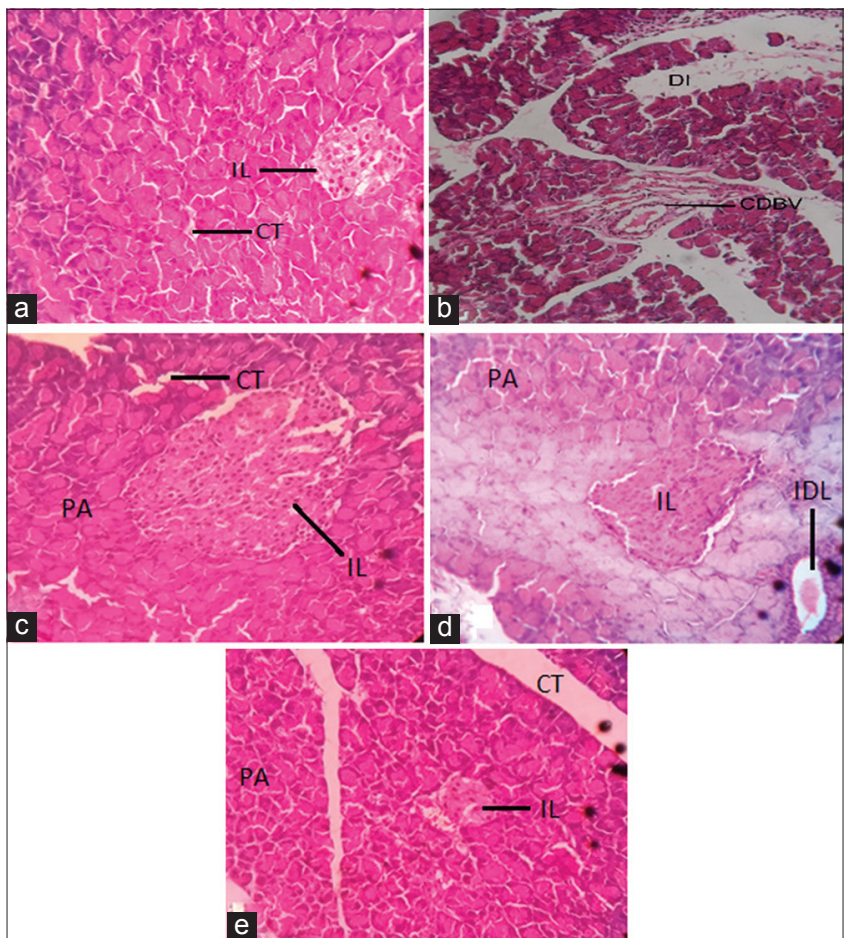

Fig. 3: Photomicrographs of a section of pancreas showing histological changes. (a) Normal control, (b) diabetic rats, (c) diabetic rats treated with Glibenclamide, (d) diabetic rats treated with ethanol extract of C. phlomidis $(200 \mathrm{mg} / \mathrm{kg})$, and

(e) diabetic rats treated with ethanol extract of Clerodendrum phlomidis (400 mg/kg). IL: Islets of Langerhans, PA: Pancreatic cells, CT: Connective tissue, ILD: Interlobular duct, CDBV: Congested dilated blood vessels, DI: Destroyed islets (blank spots)

HbA1c test helps to determine the average blood glucose levels for the preceding 3 months. In diabetic condition, high levels of HbA1c are observed due to the non-enzymatic reaction between glucose present in the plasma and the $\beta$ chain. The glucose molecule circulating in the blood binds to hemoglobin giving rise to hyperglycemic condition [27]. There was a significant decrease in the HbA1c levels in the group treated with C. phlomidis ethanol root extract at $400 \mathrm{mg} / \mathrm{kg}$ dose in comparison to the positive control.

One of the complications of diabetes mellitus is liver damage. Insulin resistance may lead to liver damage causing cirrhosis and liver failure. MDA is a by-product of lipid peroxidation which helps to detects tissue damage caused by the free radical reaction. In diabetic condition, the concentration of MDA is decreased due to the free radical formation by lipid peroxidation. This causes an increase in oxidative stress as a result of high levels of peroxides [28]. MDA levels were restored to normal range in the extract treated group at a higher dose of $400 \mathrm{mg} / \mathrm{kg}$ and comparable with the standard glibenclamide. Reduced glutathione is one of the antioxidant enzymes which protect the liver cells from oxidative damage. In diabetic condition, the reduced glutathione levels are decreased due to increase in oxidative stress caused on the liver [26]. The level of reduced glutathione was increased significantly in the animals treated with ethanol root extract of $C$. phlomidis at both the doses (200 and $400 \mathrm{mg} / \mathrm{kg}$ ) when compared to positive control.

Liver also plays a significant role in the regulation of carbohydrate metabolism. Glycogen synthesis is impaired in a diabetic condition causing accumulation of glycogen in the liver. This occurs due to the dysfunction of liver glycogen synthase which leads to abnormalities in liver enzyme activity [29]. The group treated with C. phlomidis ethanol root extract at a dose of $400 \mathrm{mg} / \mathrm{kg}$ showed an increase in the liver glycogen level when compared to positive control. The glucose tolerance test is done to determine the body's capability to use glucose. This test helps to detect pre-diabetic and diabetic condition [25]. The group treated with ethanol extract at a dose of $200 \mathrm{mg} / \mathrm{kg}$ showed a decrease in blood glucose level between 30 and 90 min whereas extract dose of $400 \mathrm{mg} / \mathrm{kg}$ significantly decreases the blood glucose level only at $90 \mathrm{~min}$. It was found that the root extract of C. phlomidis has the potential to lower the blood glucose level after induction of hyperglycemia by an overload of glucose.

The antidiabetic activity of $C$. phlomidis leaf has been reported by Gopinathan and Naveenraj [30]. In their study, a marked decrease in the levels of biochemical parameters such as blood glucose, liver glycogen, and HbA1c was observed which was comparable with the standard drug. The findings of the present study correlate with the reported antidiabetic activity of $C$. Phlomidis leaf which substantiates the traditional use of $C$. phlomidis in the treatment of diabetes.

Several studies have corelated the antidiabetic activity of the medicinal plants with the presence of phenolic compounds [31,32]. The preliminary phytochemical screening showed the presence of flavonoids which may be responsible for the antidiabetic activity. The extract also showed the presence of alkaloids in the preliminary organic analysis which have also been reported to possess antidiabetic effect $[33,34]$. Hence, these phytoconstituents may be responsible for the antidiabetic activity of $C$. Phlomidis root.

\section{CONCLUSION}

The present study confirms the antidiabetic activity of ethanol root extract of $C$. phlomidis. The study also substantiates the traditional use of $C$. phlomidis in the treatment of prameha (diabetes mellitus) in Ayurveda. Further isolation of active principle responsible for the hypoglycemic activity has to be undertaken which will provide a lead molecule for the treatment of diabetes.

\section{ACKNOWLEDGMENT}

The authors are thankful to the staff and the management of the Faculty of Pharmacy, M. S. Ramaiah University, of Applied Sciences, Bengaluru, Karnataka, India.

\section{AUTHORS' CONTRIBUTIONS}

Mrunal Shanbhag, Postgraduate student in the Department of Pharmacognosy, performed the experimental work and manuscript writing. Gowri Radhakrishnan, Assistant Professor, Department of Pharmacognosy designed, guided the experimental work and edited the manuscript.

\section{CONFLICTS OF INTEREST}

The authors do not have any conflicts of interest.

\section{REFERENCES}

1. Boukhris M, Bouaziz M, Feki I, Jemai H, El Feki A, Sayadi S, et al. Hypoglycemic and antioxidant effects of leaf essential oil of Pelargonium graveolens L'hér. In alloxan induced diabetic rats. Lipids Health Dis 2012;11:81.

2. Saravanan R, Pari L. Antihyperlipidemic and antiperoxidative effect of diasulin, a polyherbal formulation in alloxan induced hyperglycemic rats. BMC Complement Altern Med 2005;5:1-8.

3. Tripathi KD. Essentials of Medical Pharmacology. $6^{\text {th }}$ ed. New Delhi: Jaypee Brothers Medical Publishers (P) Ltd.; 2009. p. 254-74.

4. Yoganarasimhan SN. Medicinal Plants of India (Tamil Nadu). Bangalore: Interline Publishing Private Ltd.; 2000. p. 256-410.

5. Sharma PV. Dravyaguna-Vijnana. Vol. II. Varanasi: Chaukhambha Bharati Academy; 2005. p. 221-2.

6. Anonymous. The Ayurvedic Pharmacopoeia of India, Part-I. Vol. 3. Civil Lines, New Delhi: Ministry of Health and Family Welfare, Department of ISM \& H, Government of India; 2003. p. 3.

7. Nadkarni KM. Indian Materia Medica. Vol. I. Bombay: Popular Prakashan; 1993. p. 35. 
8. Yoganarasimhan SN. Medicinal Plants of India (Tamil Nadu). Vol. II. Bangalore: Cyber Media; 2000. p. 145.

9. Singh PR. A systematic review on Indian floral biodiversity as eminent reserves for alternative treatment strategy of diabetes mellitus. Int $\mathrm{J}$ Pharm Pharm Sci 2016;8:10-9.

10. Kar MK, Swain TR, Mishra SK. Antidiabetic activity of Clerodendrum serratum (L.,) Moon leaves in streptozotocin-induced diabetic rats. Asian J Pharm Clin Res 2014;7:260-3.

11. Panigrahi BK, Mishra SK, Sahu SK. Antidiabetic effects of Clerodendrum viscosum, vent. World J Pharm Sci 2015;3:1944-8.

12. Panigrahi BK, Mishra SK, Sahu SK. Antidiabetic effects of Clerodendrum inerme (L) Gaertn. Int J Pharm Pharm Res 2015;4:248-56.

13. Sharma PC, Yelne MB, Dennis TJ. Database on Medicinal Plants used in Ayurveda. Vol. 2. New Delhi: Central Council for Research in Ayurveda and Siddha, Government of India; 2002. p. 1-7.

14. Jain SK, Rao RR. Field and Herbarium Methods. New Delhi: Today and Tomorrow Printers and Publishers; 1976.

15. Harborne JB. Phytochemical Methods. $3^{\text {rd }}$ ed. London: Chapman and Hall; 1998. p. 4-7.

16. Kokate CK. Practical Pharmacognosy. New Delhi: Vallabh Prakashan; 1999. p. 107-11.

17. Chopuhan HS, Singh SK. Phytochemical analysis, antioxidant and anti-inflammatory activities of Phyllanthus simplex. J Ethnopharmacol 2011;137:1337-44

18. Pourmorad F, Hosseinimehr SJ, Shahabimajd N. Antioxidant activity, phenol and flavonoid contents of some selected Iranian medicinal plants. Afr J Biotechnol 2006;5:1142-5.

19. Anonymous. OECD Guideline for Testing of Chemicals, OEDC/OCDE 423; 2001.

20. Asgary S, Rafieian-Kopaei M, Shamsi S, Najafi S, Sahebkar A. Biochemical and histopathological study of the anti-hyperglycaemic and anti-hyperlipidemic effects of cornelian cherry (Cornus mas L.) in alloxan-induced diabetic rats. J Complement Integr Med 2014;11:63-9.

21. Prabu M, Kumuthakalavalli R. Antidiabetic potential of the Oyster mushroom Pleurotus florida (Mont.) singer. Int J Curr Pharm Res 2017:9:51-4.

22. Lachin T, Reza H. Anti-diabetic effect of cherries in alloxan induced diabetic rats. Recent Pat Endocr Metab Immune Drug Discov
2012;6:67-72

23. Paglia DE, Velentine WN. Studies on the quantitative and qualitative characterization of erythrocyte glutathione peroxidase. J Lab Clin Med 1967;70:159-68.

24. Van Der Vies J. Two methods for the determination of glycogen in liver. Biochem J 1954;57:410-6.

25. Sornalakshmi V, Soris T, Paulpriya K, Lincy P, Mohan VR. Oral glucose tolerance test (OGTT) in normal control and glucose induced hyperglycemic rats with Hedyotis leschenaultiana DC. Int J Toxicol Pharmacol Res 2016;8:59-62.

26. Mohamed J, Nafizah NA, Zariyantey AH, Budin SB. Mechanism of diabetes-induced liver damage the role of oxidative stress and inflammation. Sultan Qaboos Univ Med J 2016;16:132-41.

27. Ananthi J, Prakasam A, Pugalendi KV. Antihyperglycemic activity of Eclipta alba leaf on alloxan-induced diabetic rats. Yale J Biol Med 2004;76:97-102

28. Mahreen R, Mohsin M, Nasreen Z, Siraj M, Ishaq M. Significantly increased levels of serum malondialdehyde in Type 2 diabetics with myocardial infraction. Int J Diabetes Dev Ctries 2010;30:49-51.

29. Levinthal GN. Liver diseases and diabetes mellitus. Clin Diabetes 1999; $17: 73$.

30. Gopinathan S, Naveenraj D. Antidiabetic activity of Clerodendrum phlomidis Linn. and Gymnema sylvestre Linn. in alloxan induced diabetic rats - A comparative preclinical study. World J Pharm Res 2014;3:1640-75.

31. Jadhav R, Puchchakayala G. Hypoglycemic and antidiabetic activity of flavonoids: Boswellic acid, ellagic acid, Quercetin, Rutin on streptozotocin-nicotinamide induced Type 2 diabetic rats. Int J Pharm Pharm Sci 2012;4:251-6

32. Vessal M, Hemmati M, Vasei M. Antidiabetic effect of Quercetin in streptozotocin-induced diabetic rats. Comp Biochem Physiol C Toxicol Pharmacol 2003;135C:357-64.

33. Gaikwad SB, Mohan GK, Rani MS. Phytochemicals for diabetes management. Pharm Corps 2014;5:11-28

34. Agarwal R, Sethiya NK, Mishra SH. Antidiabetic activity of alkaloids of Aerva lanata roots on streptozotocin - Nicotinamide induced Type-II diabetes in rats. Pharm Biol 2013;51:635-42. 